\title{
IMPACT OF AIRCRAFT TRAFFIC EMISSIONS ON OZONE FORMATION AT THE RIO DE JANEIRO URBAN AREA
}

\author{
Guimarães, C.S. ${ }^{1}$, Arbilla, G. ${ }^{1}$, Corrêa, S.M. ${ }^{2}$, Gatti, L.V. ${ }^{3}$ \\ ${ }^{1}$ Institute of Chemistry, Federal University of Rio de Janeiro, Brazil \\ ${ }^{2}$ Faculty of Technology, State University of Rio de Janeiro, Brazil \\ ${ }^{3 c}$ Institute of Energy and Nuclear Research, Brazil
}

\begin{abstract}
Data for speciated volatile organic compounds (VOC) evaluated in Santos-Dumont Airport and Antonio Carlos Jobim International Airport in Rio de Janeiro, Brazil, are reported. VOC were evaluated by gas chromatography with flame ionization detection (GC - FID) and mass spectrometry (GC - MS), following the U.S. EPA TO - 15 methodology. At SantosDumont Airport were quantified $1376 \mu \mathrm{g} \mathrm{m}^{-3}$ of VOCs $10 \mathrm{~m}$ from runway, $408 \mathrm{\mu g} \mathrm{m}^{-3}$ inside the airport building, and $116 \mu \mathrm{g} \mathrm{m}^{-3}$ outside the airport area. At the taxiway area of the International Airport a total of $190 \mathrm{\mu g} \mathrm{m}^{-3}$ of VOC were quantified. Toluene, the most abundant compound near the Santos-Dumont Airport runway, was obtained in a non-significative concentration outside the airport area. This fact suggests that this area is not noticeably impacted by air traffic. A computational model was developed using the OZIPR program and the SAPRC mechanism. Calculated ozone concentrations are higher than values for downtown area of Rio de Janeiro city. Simulated results show that, for the runway in SantosDumont Airport, olefins and aromatics contribute in $57 \%$ and $15 \%$, respectively, to ozone formation, toluene being the major contributor. Cis-2-butene is the most reactive species regarding $\mathrm{OH}$ reaction.
\end{abstract}

Keywords: aircraft emissions, volatile organic compounds, ozone, reactivity.

Resumo - Dados da especiação de Compostos Orgânicos Voláteis (COVs) avaliados no Aeroporto Santos Dumont e Aeroporto Internacional Antônio Carlos Jobim no Rio de Janeiro, Brasil, são reportados. COVs foram avaliados por cromatografia gasosa com detecção por ionização na chama e espectrometria de massas (CG-DIC/EM), de acordo com a metodologia U.S.EPA TO-15. No Aeroporto Santos Dumont foram quantificados $1376 \mathrm{\mu g} \mathrm{m}^{-3}$ de COVs a $10 \mathrm{~m}$ da pista, $408 \mathrm{\mu g} \mathrm{m}^{-3}$ dentro do prédio do aeroporto e $116 \mu \mathrm{g} \mathrm{m}^{-3}$ fora da área do aeroporto. $\mathrm{Na}$ área de taxiamento do Aeroporto Internacional foram quantificados $190 \mu \mathrm{g}$ $\mathrm{m}^{-3}$. Tolueno, o mais abundante composto na pista do Aeroporto Santos Dumont foi obtido em níveis insignificantes fora da área do aeroporto. Este fato sugere que esta área não é impactada relevantemente pelo tráfego aéreo. Um modelo computacional foi desenvolvido usando o modelo de trajetórias OZIPR e o mecanismo químico SAPRC. As concentrações de ozônio calculadas foram mais altas que os valores obtidos para o centro do Rio de Janeiro. Os resultados simulados mostraram que, na pista do Aeroporto Santos Dumont, as olefinas e os aromáticos contribuem em $57 \%$ e $15 \%$, respectivamente, na formação do ozônio, sendo o tolueno o principal precursor. Cis-2-buteno é a espécie mais reativa com relação à reação com o radical $\mathrm{OH}$.

Palavras-chave: emissões de aeronaves, compostos orgânicos voláteis, ozônio, reatividade. 


\section{Introduction}

Environmental pollution due to emissions from aircraft is likely to increase in severity with the growth of flying. Fifteen years ago, these emissions were considered to be insignificant, but since then this point of view has been reviewed.

Since commercial aircraft spend most of their flight time in cruise mode and their emissions occur basically in the upper troposphere and lower stratosphere, research has focused mainly on the impact of their exhaust at regional and global scales. On other hand, some authors focused their attention on the air quality in the vicinity of airports.

According to data of Price and Probert (1995), amounts of emitted pollutants depend on the operation mode. Airport emissions arise from gate, taxi, take-off and landing operations. During take-off and climb-out, $\mathrm{NO}_{\mathrm{x}}$ is the main pollutant, while during taxi / idle, $\mathrm{CO}$ accounts for the main emission.

In 1989, jet aircraft contributed with about $0.3 \%$ of the total hydrocarbons emitted into the ground level atmosphere, representing a relatively unimportant emission source. The typically emitted hydrocarbons are ethane, ethene, benzene and toluene (PRICE and PROBERT, 1995). Only a few studies of aircraft emissions airport operations have been published.

Underwood et al. (2001) estimated the impact of postulated airport growth scenario on the air quality in the vicinity of 23 UK regional airports for the years 2005 and 2010, focusing on the pollutants $\mathrm{NO}_{2}$ and $\mathrm{PM}_{10}$. Results for 2015 and 2030 were also reported (UNDERWOOD et al. 2001).

Popp et al. (1999) measured $\mathrm{NO}_{2} / \mathrm{CO}_{2}$ emission ratios from in-use commercial aircraft at Heathrow Airport. Heland and Schäfer (1998) and Schäfer et al. (2000) determined $\mathrm{CO}_{2}, \mathrm{H}_{2} \mathrm{O}, \mathrm{CO}$ and $\mathrm{NO}$ exhaust mixing ratios as a function of engine power settings. Schäfer et al. (2003) determined idle emissions from in-service airplanes.

Herndon et al. (2004) simultaneously determine $\mathrm{NO}, \mathrm{NO}_{2}$ and $\mathrm{CO}_{2}$ within $350 \mathrm{~m}$ of a taxiway and $550 \mathrm{~m}$ of a runway at John F. Kennedy Airport. Recently, Unal et al. (2005) quantified the impact of aircraft emissions, in regards to $\mathrm{PM}_{2.5}$ and ozone, in the HartsfieldJackson Atlanta International Airport, the busiest airport in the world based on passenger traffic.

To our knowledge, little work has been published in Brazil. Simões and Schaeffer (2005) presented an inventory of $\mathrm{CO}_{2}$ emissions by aircraft activities and a trend projection until 2023. The authors report that $\mathrm{CO}_{2}$ emissions by the air transportation sector in Brazil increased from $5,000 \mathrm{Gg}$ in 1984 to $10,000 \mathrm{Gg}$ in 2002 and estimated that this value will triplicate by 2020 . Several studies showed that there is a direct link between the expansion rate of the air transportation sector and the level of economic activity in Brazil (SCHAFER and VICTOR 1999; LEE et al. 2001).

Data from INFRAERO (2005) shows that about 75 million of passengers are annually transported in Brazil. Energy consumption by Brazil's air transportation sector $(96.3 \%$ aviation kerosene) increased from 170 tons of oil equivalent in 1984 to 3,000 tons of oil equivalent in 2002 (MME, 2003).

Volatile organic compounds (VOC) play a major role in urban and regional atmospheric chemistry as precursors of photochemical gas phase and particulate products (FINLAYSONPITTS and PITTS 2000). Many of them also have possible adverse health effects (SINGH et al., 1981; GROSJEAN, 1990). For this reason, were reported here data for speciated VOC in the vicinity of the two main airports in the city of Rio de Janeiro, the first work in Brazil, where VOC from aircraft emissions were identified and quantified.

\section{Experimental Methods}

The samples were collected in the two main airports of the city of Rio de Janeiro, Brazil. The Metropolitan Area of Rio de Janeiro, Brazil, has a population of 11 million in an area of 6,500 $\mathrm{km}^{2}$.

Santos-Dumont Airport is a national airport located $1 \mathrm{~km}$ away from downtown $\left(22^{\circ} 54\right.$ 'S, 43'10'W, elevation $3 \mathrm{~m}$ ). In 2004 this airport had an average of 80,000 landings and take-offs and about 5 million passengers, distributed in six air companies. The samples were collected $1.5 \mathrm{~m}$ above the ground in three different locations: about $10 \mathrm{~m}$ from runway, in the boarding area inside the building, and about $100 \mathrm{~m}$ away from the airport area (one sample in each local).

The International Airport of Rio de Janeiro - Antonio Carlos Jobim is located $20 \mathrm{~km}$ from downtown $\left(22^{\circ} 48^{\prime} \mathrm{S}, 43^{\circ} 15^{\prime} \mathrm{W}\right.$, altitude $\left.9 \mathrm{~m}\right)$. In 2004 , the airport had an average of 78,000 landings and take-offs and about 6 million passengers distributed in 17 air companies. 
Three samples were collected at $1.5 \mathrm{~m}$ above the ground in the taxiway area. Both airports are located in a well ventilated area by the Guanabara Bay.

Samples were collected in $1.8 \mathrm{~L}$ stainless steel canisters. The analysis was performed by gas chromatography with flame ionization detection and mass spectrometry detection (GCFID/MSD). The method follows U.S. EPA guidelines (U.S. EPA Compendium TO-15 Method 1999). Briefly, $100 \mathrm{~mL}$ aliquot of air from the canister samples were loaded on a cryo-trap $\left(-180^{\circ} \mathrm{C}\right)$, desorbed at $400^{\circ} \mathrm{C}$ and injected on a GC column where the sample is cryo-focused at $-50^{\circ} \mathrm{C}$. The column was a DB-1 capillary column, $60 \mathrm{~m} \times 0.32 \mathrm{~mm} \times 1.0 \mu \mathrm{m}$. The temperature was held at $-50^{\circ} \mathrm{C}$ for $2 \mathrm{~min}$, and raised from $-50^{\circ} \mathrm{C}$ to $+200{ }^{\circ} \mathrm{C}$ at $6{ }^{\circ} \mathrm{C} \mathrm{min}{ }^{-1}$. After leaving the capillary column, the sample was analyzed simultaneously by FID and MSD. The analyses were carried out using a Varian 3800 gaschromatograph and a Saturn 2000 mass selective detector. The VOCs were identified by a NIST library and quantified using standard mixtures of 4 alkanes, 5 alkenes, 4 aromatics and a TO-14 standard mixture. To evaluate the results reproducibility, all samples were run by duplicate and the difference was lower than $5 \%$. Blank runs were also performed before each sample analysis.

\section{Results and Discussion}

Results for the four sampling sites are shown in Table 1. In site 1 (10 $\mathrm{m}$ from runway) a total of $821 \mathrm{\mu g} \mathrm{m}^{-3}$ of VOC were detected, which represent $60 \%$ of total compounds detected in that location $\left(1376 \mu \mathrm{g} \mathrm{m}^{-3}\right)$. In mass units, the main compounds in order of decreasing concentrations, were toluene, benzaldehyde, isopentane, $n$-butane, $n$-pentane, 3-methyl-1butene, 2-methyl-1-propene, 2-methylpentane, cis 2-butene, 1-butene and 1,1dimethylcyclopropane which represent $1015 \mu \mathrm{g}$ $\mathrm{m}^{-3}(72 \%$ of total). Toluene accounts for $15 \%$ of total, isopentane for $14 \%$ and the two main alkanes ( $n$-butane and $n$-pentane) for $17 \%$.

In Site 2 (inside the airport building), a total of $408 \mu \mathrm{g} \mathrm{m}^{-3}$ were detected, $54 \%$ being quantified with standard mixtures. The total level of VOC evaluated inside the building is only $30 \%$ of the value obtained near the runway. The main compounds are also different: $n$-butane, isobutane, hydroxymethylcyclopropane, acetone, propane and ethane, that accounts for $65 \%$ of total. These results and the comparison with the main compounds found in Site 1 and in Site 3, suggest that VOC determined inside the building are probably due to anthropogenic emissions, other than aircraft and vehicles.

In Site 3, outside the airport area, a total of $116 \mathrm{\mu g} \mathrm{m}^{-3}$ were quantified. This value is about ten times lower than the concentration obtained near the runway. In a ppbC basis the total concentration outside the airport is $464 \mathrm{ppbC}$ and near the runway is $2390 \mathrm{ppbC}$, a figure five times higher. The low values obtained outside the airport may be attributed to the characteristics of that area. The area is well ventilated, near the Guanabara Bay, surrounded by a park, with low impact from vehicular emissions.

The main compounds were propane, isopentane, ethane and $n$-pentane which account for $44 \%$ of total. Propane was found to be the most abundant pollutant. A similar result was obtained in Porto Alegre, Brazil, by Grosjean et al. (1998). Propane, ethane and isopentane were also determined the most abundant non-aromatic hydrocarbons during a photochemical smog episode in Southern California (FRASER et al., 1997). In the other side, toluene, the most abundant compound near the runway, was obtained in a non-significative concentration outside the airport area. These facts suggest that the area is not noticeably impacted by air traffic.

In Site 4 (International Airport), $97 \mathrm{\mu g} \mathrm{m}^{-3}$ of VOC were quantified. This value is 8.4 times lower than the value determined in Site 1. In mass unit, the main compounds, in order of decreasing concentrations, were ethane, $n$ butane, propane, $n$-pentane, isopentane, $n$ decane, 3-methyl-1-butene, 2-methyl-1-propene, toluene and $m$-dichlorobenzene. The sampling location, the taxiway area, is less impacted by aircraft emissions than the taxiway area in Santos-Dumont Airport.

\section{Computational results}

Computer simulations were performed using an empirical trajectory model implemented in OZIPR (GERY and CROUSE 1990) and the photochemical mechanism SAPRC (CARTER, 1990).

The details of the computational procedure were discussed in a previous paper (MARTINS et al., 2002). The model was used to construct a base case, which is a typical scenario of downtown Rio de Janeiro. It uses a combination of input data that were chosen to be 
relevant and representative of Rio de Janeiro urban area. Additionally, the base case was a reference to examine the effect of aircraft emissions on the calculated ozone concentrations.

Experimental meteorological data, listed in Table 2, were collected by FEEMA (2004a) at the monitoring station located about $1 \mathrm{~km}$ away from Santos-Dumont Airport for August 2004. Meteorological parameters (temperature and relative humidity) are average values. Mixing heights are estimated parameters on the basis of atmosphere temperature and pressure profiles available at IAG-USP home page (2004). No experimental data are available for Rio de Janeiro. Therefore, in this work, the absolute value of $\mathrm{CO}$ emissions was used as adjustable parameter in order to set experimental concentrations. An error in the mixing height might be corrected by changing the emissions. The solar actinic flux was set for August 18, 2004.

The $\mathrm{VOC} / \mathrm{NO}_{x} / \mathrm{CO}$ emission ratios were calculated in consistence with the emission inventory for Rio de Janeiro Metropolitan Area (FEEMA 2004b) as $\mathrm{NO}_{x} / \mathrm{CO}=0.191$ and $\mathrm{VOC} / \mathrm{CO}=0.170$ (on a mass basis).

This is a crude approximation since emission ratios in the airport area are expected to be different, due to aircraft contribution to $\mathrm{CO}$ and $\mathrm{NO}_{x}$ emissions. The consequences of this approximation will be discussed later.

Initial concentrations of $\mathrm{CO}$ and $\mathrm{NO}_{x}$ were $1.01 \mathrm{ppm}$ and $273.0 \mathrm{ppb}$, respectively, and were based on the experimental data obtained at the monitoring station during August, 2004. VOC initial concentration, $1.01 \mathrm{ppmC}$, and specified VOC values were obtained by Corrêa (2003) for the same location. Calculated ozone concentrations are in reasonable agreement with experimental results, with a difference less than $8.8 \%$ for the maximum value obtained at $12: 00 \mathrm{~h}$. A further setting was not considered necessary since this scenario was used only for comparison with the airport simulations.

\section{VOC Composition Impact on Ozone Concentrations}

In this section the contribution of the VOC mixtures determined in Sites $1-3$ of SantosDumont Airport and Site 4 (International Airport) to the formation of ozone was calculated.

Ozone concentrations were re-calculated for hypothetical scenarios with conditions identical to those of the base case, except for VOC. The total concentration of VOC, other than methane, ethanol and aldehydes, was set to 6.03 ppmC, the determined value in Site 1 of SantosDumont Airport. Total concentration of VOC was set identical in all simulations for a better comparison of the mixtures reactivities.

Aldheydes, ethanol and $\mathrm{CH}_{4}$ concentrations were not determined in this work. Mean values for downtown Rio de Janeiro were used (CORRÊA, 2003). VOC compositions for each Site are presented in Table 3. Calculated ozone concentrations are shown in Figure 1.

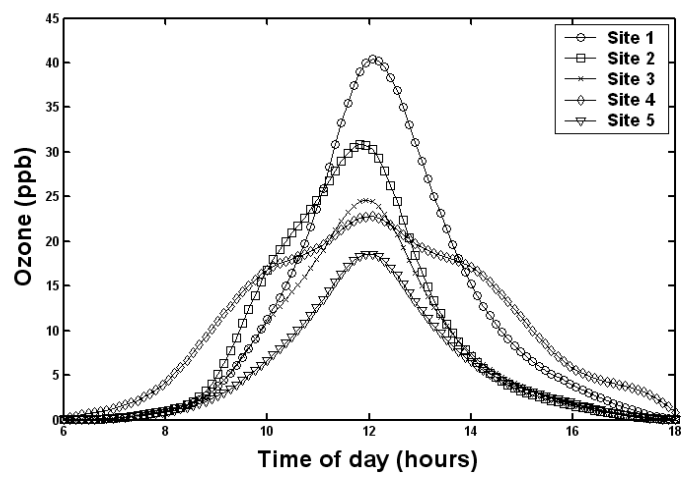

Figure 1 - Simulated ozone concentrations for $10 \mathrm{~m}$ from runway in Santos-Dumont Airport (Site 1), inside the building (Site 2), outside SantosDumont Airport area (Site 3), in the taxiway area of the International Airport (Site 4) and downtown (Site 5).

Maximum ozone concentration calculated for Site 1 and 4 are, respectively, $77 \%$ and $34 \%$ higher than the calculated value for downtown. As will be shown, this result may be attributed to the enrichment of the mixture in alkenes and aromatics.

The concentration of secondary pollutants, mainly ozone, is related to those of precursors, VOC and $\mathrm{NO}_{x}$, in ways that are, under many conditions, highly non-linear (FINLAYSON - PITTS and PITTS, 2000). In practice, ozone concentrations depend on $\mathrm{VOC} / \mathrm{NO}_{\mathrm{x}}$ ratios for this particular scenario.

In this simulation, the ratio 1.76 (in ppmC units) for the initial concentrations of VOC and $\mathrm{NO}_{x}$, correspond to the upper region of the ozone isopleths, were ozone levels are VOC limited. Here, reducing VOC, at constant $\mathrm{NO}_{x}$ results in a reduction of ozone concentrations, while reducing $\mathrm{NO}_{x}$, at constant VOC, actually leads to an increase in ozone levels. This value, as well as the emission ratio, was determined for downtown.

Pison and Menut (2004) found that $\mathrm{NO}_{x}$ air traffic emissions have a more important 
impact than VOC emissions, particularly during the night and near the sources. $\mathrm{VOC} / \mathrm{NO}_{\mathrm{x}}$ emission ratios were computed for the altitude 0 - $50 \mathrm{~m}$ over Paris area, where one national airport and two international airports are located less than $30 \mathrm{~km}$ away from the downtown. Values between 0 and 1.1 (in mass units) were calculated for air traffic emissions, while values between 1.9 and 5.5 were obtained for other anthropogenic emissions. The relative contribution of aircraft emissions to the total emitted mass is $+15.3 \%$ in $\mathrm{NO}_{x}$ and $+2.1 \%$ in VOC. These facts led to a reduction of ozone levels through the reaction of $\mathrm{O}_{3}$ and $\mathrm{NO}$ and the competition of $\mathrm{NO}_{2}$ and $\mathrm{VOC}$ for the $\mathrm{OH}$ radical, forming $\mathrm{HNO}_{3}$ (PISON and MENUT 2004).

For Rio de Janeiro, the emission inventory (FEEMA 2004b) used in these simulations shows a $\mathrm{VOC} / \mathrm{NO}_{x}$ ratio of 0.89 (in mass units). This value is similar to the upper limit calculated by Pison and Menut (2004) and so a lower impact of $\mathrm{NO}_{x}$ may be expected.

Maximum values for ozone concentrations in Site 3 (outside the airport area) and in downtown were $24.6 \mathrm{ppb}$ and $22.8 \mathrm{ppb}$, respectively, a difference of about $8 \%$, which supports the conclusion that Site 3 is not impacted by airport activities.

The calculated maximum for the VOC mixture found inside the building is $70 \%$ lower than in Site 1. This fact is due to the change in VOC speciation, mainly the olefin content which decreased from $12 \%$ in Site 1 to $0.8 \%$ inside the building. As discussed in the following paragraphs, the alkenes group is the most reactive.

The influence of each group in the formation of ozone is shown in Figure 2. Ozone concentrations were re-calculated for Site 1. In each run the mixing ratio of a particular group was set equal to zero while the other fractions were not changed. For example, in run identified as "without alkanes" the fractions of the alkanes groups were set to zero, while the other fractions and the total amount of VOC were kept equal to those of Site 1 (i.e. alkanes were considered as non-reactive species in that run). The main contribution to ozone formation is from the alkenes group. Maximum calculated ozone concentration is $67 \%$ lower when this group is considered non-reactive. For aromatics, the value is $27 \%$ lower.

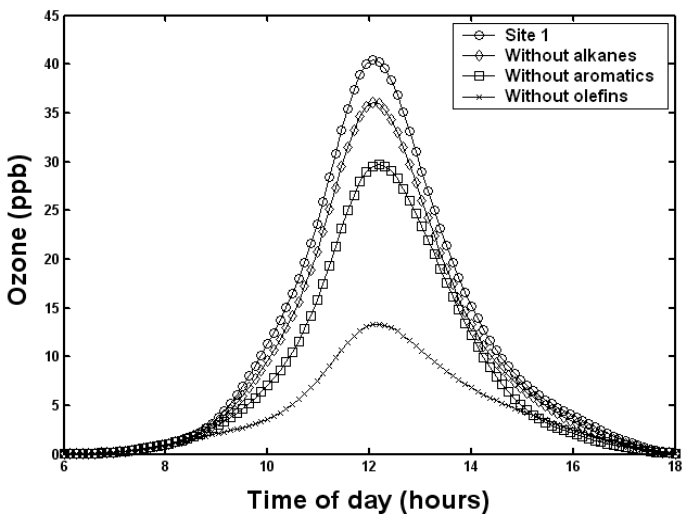

Figure 2 - Influence of the grouping in the ozone calculated concentrations.

Other runs were performed for each individual group, as shown in Figure 3. Again, the main contribution is from groups Olefins 1 and Olefins 2 , which are responsible for the formation of $27 \%$ and $41 \%$ of ozone, respectively. Aromatics 1 group (mainly benzene and toluene) and Aromatics 2 group (mainly xylenes) contribute $15 \%$ and $9 \%$, respectively. The contributions of alkanes, mainly group 1 and 2, are extremely low.

Since in the two airports the percentage of olefins and aromatics is higher than in downtown, ozone concentrations, in Figure 1, are also higher for both sites.

The relative reactivity of individual VOC was evaluated using reactivity scales. Different ranking scales of photochemical reactivity may be built. In a kinetic scale, the reaction with $\mathrm{OH}$ is evaluated by multiplying the reactive species concentration by the corresponding specific $\mathrm{OH}$ reaction rate coefficient. This is portrayed by the second entry in Table 4 and is an indicative of the efficiency of $\mathrm{OH}$ removal by the reactive species, leading to carbonyls and radicals.

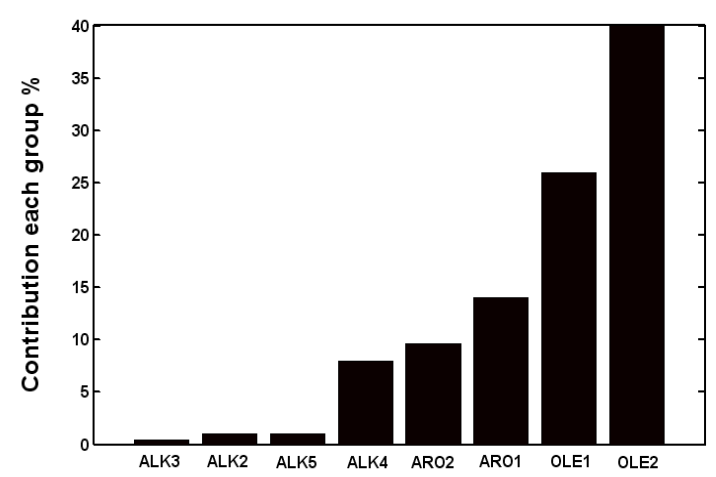

Figure 3 - Percentage of contribution of each group in ozone formation for site $1(10 \mathrm{~m}$ from runway in Santos-Dumont Airport). 
Another approach is the MIR (Maximum Incremental Reactivity) developed by Carter (1994), Bownman and Seinfeld (1995) and Derwent and Jenkin (1991) that are shown in the last entry of Table 4 and indicate how much the compound contributes to ozone formation.

As shown in Table 4 for Santos-Dumont Airport, toluene is the most abundant compound and is also the major contributor to ozone formation. Cis-2-butene is the most reactive species regarding $\mathrm{OH}$ reaction.

Although the ranking of $\mathrm{VOC}$ with respect to ozone production is not identical to that from $\mathrm{OH}$ removal, toluene, cis-2-butene, 2-methyl-1propene, 1-butene, 2-pentene, isopentane, 2methyl-1-butene are the top-ranking compounds. Considering reaction with $\mathrm{OH}$ radical, benzaldehyde appears in the sixth place. In the MIR scale it appears in the last place, with a negative coefficient. This fact is due to the formation of the peroxyacetyl radical which leads to the formation of peroxybenzoyl nitrate with a rate coefficient 2.4 times higher than the coefficient for reaction with $\mathrm{NO}$ to form $\mathrm{NO}_{2}$, precursor of ozone.

In any case, it is clear that the more productive species are toluene and alkenes. The species with the highest ozone productivities are not merely species that directly produce ozone themselves, but are those that increase the flow of radicals, which lead to an increase of ozone. The MIR coefficient for toluene is lower than the value for xylenes, cis-2-butene and 3-methyl-2pentene. Anyway the reactivity of toluene is higher because of the high concentration of this compound in the airport area.

\section{Conclusions}

In this paper, VOC emissions by aircraft traffic in two airports of the city of Rio de Janeiro were evaluated. In Site 1 toluene was the most abundant compound (15\% on a mass basis) and also the major contributor to ozone formation. Results for Site 2 show that the main compound was $n$-butane ( $43 \%$ of total in a mass basis) and toluene represents $3 \%$ of total. In Site 1, $n$-butane accounts for only $9 \%$ of total. These results suggest that VOC concentrations inside the building are mainly due to anthropogenic emissions, other than aircraft. In Site 3 the main compounds were propane, isopentane, ethane and $n$-pentane, characteristic of urban areas. Toluene concentration was also only $3 \%$ of total VOC mass.
Total VOC concentration in the International Airport is 7.2 times lower than the value determined in Santos-Dumont Airport.

Simulated results show that toluene and alkenes are the most important species in the production of ozone.

\section{Acknowledgments}

The authors thank CNPq and FAPERJ for financial support and Enga. Amélia Yamazaki (IPEN/USP) for technical assistance in the chromatographic analyses.

\section{Bibliography}

1.BOWMAN, F.M., Seinfeld, J.H. Atmospheric Chemistry of Alternative Fuels and Reformulated Gasoline Components, Prog. Energy Combust. Sci. 21 (2005) 387417.

2.CARTER, W. P. L. Development of ozone reactivity scales for organic gases, J. Air Waste Manage. Assoc. 44 (1994) 881-899.

3.CARTER, W.P.L. A detailed mechanism for the gasphases atmospheric reactions of organic compounds, Atmos. Environ. 24 (1990) 481-518.

4.CORREAA, S.M. Qualidade do Ar da Cidade do Rio de Janeiro: Sinergia entre Simulação e Monitoramento, PhD Thesis, Federal University of Rio de Janeiro, RJ, Brazil, 2003.

5.DERWENT, R.G., Jenkin, M.E., Hydrocarbons and LongRange Transport of Ozone and PAN across Europe, Atmos. Environ. 25 (1991)1661-1678.

6.FEEMA - Fundação Estadual de Engenharia do Meio Ambiente, Relatório Anual da Qualidade do Ar, Rio de Janeiro, Brazil, 2004a.

7.FEEMA - Fundação Estadual de Engenharia do Meio Ambiente, Internal Report results. Available from the Institution, 2004b.

8.FINLAYSON-PITTS, B. J., Pitts, J. Jr., Chemistry of the Upper and Lower Atmosphere: Theory, Experiments and Applications. Florida Academic Press, 2000.

9.FRASER, M.P., Cass, G.R., Simoneit, B.R.T., Air Quality Model Evaluation Data for Organics: 4. C2 - C36 Nonaromatics Hydrocarbons, Environ. Sci. Technol. 31 (1997) 2356-2367.

10.GERY, M. W., Crouse, R. R., User's Guide for Executing OZIPR, U.S. EPA, Research Triangle Park, N. C., 9D2196NASA, 1990.

11.GROSJEAN, D. Atmospheric chemistry of toxic contaminants. I Reaction rates and atmospheric persistence. J. Air Waste Manage. Assoc. 40 (1990) 1397-1402.

12.GROSJEAN, E., Rasmussen, R.A., Grosjean, D., Ambient Levels of gas Phase Pollutants in Porto Alegre, Brazil, Atmos. Environ. 32 (1998) 3371-3379.

13.HELAND, J., Schäfer, K. Determination of major combustion products in Aircraft exhausts by FTIR emission spectroscopy, Atmos. Environ. 32 (1998) 3067-3072.

14.HERNDON, S. C., Shorter, J. H., Zahniser, M. S., Nelson Jr, D. D., Jayne, J., Brown, R. C., Miake-Lye, R. C., Waitz, I., Silva, P., Lanni, T., Demerjian, K., Kolb, C.E. , Environ. Sci. Technol. 38 (2004) 6078-6084.

15.IAG - Instituto de Astronomia, Geofísica e Ciências. http://www.iag.usp.br, Brazil. Accessed August 2004.

16.INFRAERO - Empresa Brasileira de Infra-estrutura Aeroportuária.(2005). Brasília, DF, Brazil. http://www.infraero.gov.br. Accessed September 2005. 
17.LEE, J.J., Lukachko, S.P., Waitz, I.A., Schafer, A., Historical and Trends in Aircraft Performance, Cost and Emissions, Annu. Rev. Energy Environ. 26 (2001) 167-200. 18.MARTINS, M. M., Arbilla, G., Moreira, A., Moreira, L.F.R. Ozone Air Quality Modeling. A Case Study: A Heavily Vehicle Impacted Urban Avenue in Rio de Janeiro, J. Brazilian Chem. Society 13 (2002) 308-317.

19.MME - Ministry of Mines and Energy (2003). http://www.mme.gov.br . Brasilia, DF, Brazil. Accessed September 2005.

20.PISON, I., Menut, L., Quantification of the impact traffic emissions on Tropospheric ozone over Paris area, Atmos. Environ. 38 (2004) 971-983.

21.POPP, P.J., Bishop, G.A., Stedman, D.H., Method for Commercial Aircraft Nitric Oxide Emission Measurements. Environ. Sci. Technol. 33 (1999) 1542-1544.

22.PRICE, T., Probert, D., Environmental Impacts of Air Traffic, Applied Energy, 50 (1995) 133-162.

23.SCHAFER, A., Victor, D.G., Global passenger travel: implications for carbon dioxide emissions, Energy 24 (1999) 657-679.

24.SCHÄFER, K., Heland, J., Lister, D.H., Wilson, C.W., Howes, R.J., Lindermeir, E., Birk, M., Wagner, G., Haschberger, P., Bernard, M., Legras, O., Wiesen, P., Kurtenbach, R., Brockmann, K.J., Kriesche, V., Hilton, M., Bishop, G., Clarke, R., Workman, J., Caola, M., Geatches, R., Burrows, R., Black, J.D., Herve, F., Vally, J.,. Nonintrusive Optical Measurements of Aircraft Engine Exhaust Emissions and Comparison with Standard Intrusive
Techniques, Applied Optics 39 (2000) 441- 455.

25.SCHÄFER, K., Jahn, C., Sturn, B. L., Bacher, M., Aircraft emission measurements by remote sensing methodologies at airports, Atmos. Environ. 37 (2003) 5261-5271.

26.SIMÕES, A.F., Schaeffer, R., The Brazilian air transportation sector in the context of global climate change: $\mathrm{CO} 2$ emissions and mitigation alternatives, Energy Conversion \& Management 46 (2005) 501-513.

27.SINGH, H.B., Salas, L.J., Smith, A. J., Shioeishi, H., Measurements of some potentially hazardous organic chemicals in urban environments, Atmos. Environ. 15 (1981) 601-602.

28.U.S. EPA Compendium Method TO-15, Determination of Volatile Organic Compounds (VOCs) in Air Collected in Specially by Gas Chromatography / Mass Spectrometry (GC / MS), Center for Environmental Research Information, Cincinnati, OH 45268, 1999.

29.UNAL, A., Hu, Y., Chang, M.E., Odman, M.T., Russel, A.G., Airport related emissions and impacts on air quality: Application to the Atlanta International Airport. Atmos. Environ. 39 (2005) 5787-5798.

30.UNDERWOOD, B.Y., Brightwell, S. M., Peirce, M. J., Walker, C. T., Air Quality at UK Regional Airports in 2005 and 2010, AEAT/ENV/0453 Issue 2, http://www.airquality.co.uk/archive/reports/cat07/aeat-env-r0453.pdf.42. Accessed September 2005.

Table 1 - Compounds identified in canister samples collected in Santos-Dumont Airport and International Airport, in Rio de Janeiro $\left(\mu \mathrm{g} \mathrm{m}^{-3}\right)$.

\begin{tabular}{|c|c|c|c|}
\hline \multirow{2}{*}{$\begin{array}{c}\text { Compound } \\
\text { (using standard mixtures) }\end{array}$} & \multicolumn{2}{|c|}{ Santos-Dumont } & \multirow{2}{*}{$\begin{array}{c}\text { International Airport } \\
\qquad(\mathrm{N}=3) \\
\text { Site } 4\end{array}$} \\
\hline & Site 1 & Site 3 & \\
\hline Ethane & N.D & 12 & 32 \\
\hline$n$-Propane & 1 & 17 & 11 \\
\hline$n$-Butane & 125 & 7 & 16 \\
\hline Isobutane & 35 & 1 & 2 \\
\hline$n$-Pentane & 108 & 10 & 9 \\
\hline Isopentane & 190 & 12 & 8 \\
\hline$n$-Hexane & 22 & 2 & 2 \\
\hline Propene & N.D & 1 & 1 \\
\hline 1-Butene & 35 & N.Q & 1 \\
\hline Cis 2-Butene & 40 & N.Q & 1 \\
\hline 2-Pentene & 23 & N.Q & 1 \\
\hline Cis 2-Hexene & 5 & N.Q & 1 \\
\hline Benzene & N.D & N.Q & 3 \\
\hline Toluene & 211 & 3 & 4 \\
\hline Ethylbenzene & 6 & 1 & 1 \\
\hline$o$-xylene & 6 & 2 & 1 \\
\hline$p$-Xylene & 7 & 1 & 1 \\
\hline$m$-Xylene & 7 & 1 & 2 \\
\hline Total & 821 & 70 & 97 \\
\hline (using analog compounds) & & & \\
\hline 2,2-Dimethylbutane & 2 & 1 & N.D \\
\hline 2,3-Dimethylbutane & N.D & 1 & 1 \\
\hline 3-Methylpentane & 15 & 2 & 2 \\
\hline 2-Methylpentane & 42 & 5 & 2 \\
\hline 2,4-Dimethylpentane & 2 & N.D & 0.2 \\
\hline
\end{tabular}




\begin{tabular}{|c|c|c|c|}
\hline \multirow{2}{*}{$\begin{array}{c}\text { Compound } \\
\text { (using standard mixtures) }\end{array}$} & \multicolumn{2}{|c|}{ Santos-Dumont } & \multirow{2}{*}{$\begin{array}{c}\text { International Airport } \\
(\mathrm{N}=3) \\
\text { Site } 4 \\
\end{array}$} \\
\hline & Site 1 & Site 3 & \\
\hline 2,3-Dimethylpentane & 1 & 0.3 & N.D \\
\hline Methylcyclopentane & 4 & 2 & 1 \\
\hline 1,2-Dimethylcyclopentane & 20 & 0.3 & 1 \\
\hline Ethylcyclopropane & N.D & 0.4 & N.D \\
\hline 1,2-Dimethylcyclopropane & 17 & 0.4 & 1 \\
\hline 1,1-Dimethylcyclopropane & 29 & N.D & N.D \\
\hline Cyclohexane & 13 & 3 & N.D \\
\hline 3-Methylhexane & 4 & 1 & 1 \\
\hline 1-Ethyl-2-methylcyclopropane & 1 & N.D & N.D \\
\hline 1,4-Dimethylcyclohexane & 1 & N.D & N.D \\
\hline 1-Methyl-3-ethylcyclohexane & N.D & N.D & N.D \\
\hline Methylcyclohexane & N.D & 1 & N.D \\
\hline Ethylcyclopentane & N.D & N.Q & 1 \\
\hline 3-Ethylhexane & N.D & 1 & N.D \\
\hline 2,3-Dimethylhexane & N.D & 1 & N.D \\
\hline$n$-Heptane & N.D & 1 & 0.1 \\
\hline 3,6-Dimethyloctane & N.D & 1 & N.D \\
\hline 2,3-Dimethyloctane & N.D & 0.2 & N.D \\
\hline$n$-Nonane & N.D & 1 & 1 \\
\hline$n$-Decane & N.D & N.D & 5 \\
\hline 4-Methylnonane & N.D & 1 & N.D \\
\hline 4-Methyldecane & N.D & N.D & 0.1 \\
\hline 2,4,6-Trimethyloctane & 1 & N.D & 1 \\
\hline 3,5-Dimethylheptane & N.D & N.D & N.D \\
\hline$n$-Undecane & 1 & N.D & N.D \\
\hline$n$-Dodecane & 0.4 & 0.4 & 1 \\
\hline$n$-Tridecane & N.D & N.Q & 1 \\
\hline 2-Methyl-1-propene & 43 & 2 & 6 \\
\hline 2-Methyl-1-butene & 42 & 1 & 1 \\
\hline 2-Methyl-2-butene & 16 & N.D & 2 \\
\hline 3-Methyl-1-butene & 63 & 6 & 29 \\
\hline 2,3-Dimethyl-2-butene & 2 & N.D & 1 \\
\hline 3-Methyl-2-pentene & N.Q & N.D & 0.1 \\
\hline 2-Methyl-2-pentene & N.Q & N.D & 0.2 \\
\hline 2,3-Dimethyl-2-pentene & 4 & N.D & 2 \\
\hline 2,2-Dimethyl-1-butene & 1 & N.D & N.D \\
\hline 2,3-Dimethyl-2-butene & 5 & N.Q & 1 \\
\hline 3-Methyl-2-pentene & 5 & N.Q & 0.1 \\
\hline 2-Methyl-1-pentene & 3 & N.Q & 0.3 \\
\hline 4-Methyl-2-pentene & 2 & N.D & 0.2 \\
\hline 2-Methyl-2-pentene & 4 & N.Q & 0.2 \\
\hline 3-Methyl-3-hexene & N.Q & N.D & 0.3 \\
\hline 1-Heptene & N.D & N.Q & 1 \\
\hline 1-Methylcyclopentene & N.D & N.Q & 0.1 \\
\hline 3-Methylcyclopentene & 0.4 & N.D & 0.2 \\
\hline Cyclopentene & 7 & N.Q & 1 \\
\hline 2-Methylcyclopenteno & 4 & N.D & 0.2 \\
\hline 3,4,4-Trimethyl-2-penteno & 1 & N.Q & N.D \\
\hline 2,2,4,6,6-Pentamethyl-3-heptene & 2 & N.D & 0.2 \\
\hline 1-Octene & N.Q & N.D & N.Q \\
\hline Cyclohexene & 1 & N.D & N.D \\
\hline $1,2,4,5$-Tetramethylbenzene & N.D & N.D & 2 \\
\hline n-Propylbenzene & N.D & 1 & 1 \\
\hline 1,3,5-Trimethylbenzene & 8 & 3 & 3 \\
\hline$o$-Ethyltoluene & 7 & 2 & 2 \\
\hline$m$-ethyltoluene & 4 & N.D & 1 \\
\hline$p$-Ethyltoluene & 6 & 2 & 1 \\
\hline 1,2,4-Trimethylbenzene & 4 & 1 & 2 \\
\hline
\end{tabular}




\begin{tabular}{cccc} 
Compound & \multicolumn{2}{c}{ Santos-Dumont } & $\begin{array}{c}\text { International Airport } \\
\text { (using }=3)\end{array}$ \\
& Site 1 & Site 3 & Site 4 \\
\hline 1,3,4-Trimethylbenzene & N.D & 2 & 2 \\
$p$-Isopropyltoluene & 0.2 & N.D & 2 \\
Chlorobenzene & 2 & N.D & 0.4 \\
$o$-Dichlorobenzene & 25 & N.D & 2 \\
$m$-Dichlorobenzene & 11 & 2 & 3 \\
Naphtalene & N.Q & N.D & 1 \\
$n$-Butanal & 1 & N.Q & 1 \\
1,1,2-Trichloro-2-fluoroethane & N.D & N.D & 0.1 \\
Trimethylsilanol & N.D & N.Q & 0.1 \\
Hydroxymethylcyclopropane & N.D & N.D & 0.3 \\
1,3-Pentadiene & N.D & N.D & 0.4 \\
1,4-Hexadiene & N.D & N.D & 0.2 \\
Naphthalene & N.D & N.D & 1 \\
Benzaldehyde & 128 & N.D & 2 \\
\hline Total & 555 & 46 & 93 \\
\hline
\end{tabular}

N.D - non-detected (concentration lower than $0.0001 \mu \mathrm{g} \mathrm{m}^{-3}$ detection limit) $\mathrm{N} . \mathrm{Q}$ - non-quantified (concentration lower than $0.01 \mu \mathrm{g} \mathrm{m}^{-3}$ )

Table 2 - Input parameters for the simulation of the base case. Temperature and relative humidity are average experimental values for August 2004. Mixing heights are estimated values (see text for details).

\begin{tabular}{cccc}
\hline Time & Relative humidity (\%) & Temperature $\left.\mathbf{~}^{\mathbf{O}} \mathbf{C}\right)$ & Mixing height (m) \\
\hline 06:00 a.m. & 77 & 27 & 425 \\
07:00 a.m. & 72 & 28 & 505 \\
08:00 a.m. & 68 & 29 & 596 \\
09:00 a.m. & 61 & 30 & 681 \\
10:00 a.m. & 57 & 31 & 837 \\
11:00 a.m. & 58 & 31 & 933 \\
12:00 a.m. & 57 & 32 & 975 \\
01:00 p.m. & 58 & 32 & 964 \\
02:00 p.m. & 60 & 32 & 906 \\
03:00 p.m. & 63 & 31 & 807 \\
04:00 p.m. & 67 & 30 & 714 \\
05:00 p.m. & 69 & 29 & 603 \\
06:00 p.m. & 70 & 28 & 495 \\
\hline
\end{tabular}

Table 3 - Average composition of VOC mixture used for the simulation of ozone concentrations.

\begin{tabular}{|c|c|c|c|c|c|c|c|}
\hline \multirow{3}{*}{$\begin{array}{l}\text { Compound or } \\
\text { Group }\end{array}$} & \multirow{3}{*}{ Symbol } & \multirow{3}{*}{$\begin{array}{c}\text { Reactivity } \\
\mathrm{k}_{\mathrm{OH}}\left(\mathrm{ppm}^{-1} \mathrm{~min}^{-1}\right)\end{array}$} & \multicolumn{5}{|c|}{ Fraction (on a ppmC basis) } \\
\hline & & & \multicolumn{3}{|c|}{$\begin{array}{c}\text { Santos-Dumont } \\
\text { Airport }\end{array}$} & \multirow{2}{*}{$\begin{array}{c}\text { International } \\
\text { Airport } \\
\text { Site } 4\end{array}$} & \multirow{2}{*}{$\begin{array}{l}\text { Downtown } \\
\text { Site } 5\end{array}$} \\
\hline & & & Site & Site & Site & & \\
\hline Alkanes 1 & ALK1 & $\mathrm{k}_{\mathrm{OH}}<5.0 \times 10^{2}$ & 0.000 & 0.003 & 0.007 & 0.020 & 0.020 \\
\hline Alkanes 2 & ALK2 & $5.0 \times 10^{2}<\mathrm{k}_{\mathrm{OH}}<2.5 \times 10^{3}$ & 0.001 & 0.006 & 0.016 & 0.018 & 0.021 \\
\hline Alkanes 3 & ALK3 & $2.5 \times 10^{3}<\mathrm{k}_{\mathrm{OH}}<5.0 \times 10^{3}$ & 0.047 & 0.110 & 0.010 & 0.024 & 0.010 \\
\hline Alkanes 4 & ALK4 & $5.0 \times 10^{3}<\mathrm{k}_{\mathrm{OH}}<1.0 \times 10^{4}$ & 0.107 & 0.048 & 0.054 & 0.036 & 0.047 \\
\hline Alkanes 5 & ALK5 & $\mathrm{k}_{\mathrm{OH}}>1.0 \times 10^{4}$ & 0.019 & 0.006 & 0.051 & 0.031 & 0.013 \\
\hline Olefins 1 & OLE1 & $\mathrm{k}_{\mathrm{OH}}<7.0 \times 10^{4}$ & 0.045 & 0.003 & 0.004 & 0.005 & 0.009 \\
\hline Olefins 2 & OLE2 & $\mathrm{k}_{\mathrm{OH}}>7.0 \times 10^{4}$ & 0.079 & 0.005 & 0.004 & 0.023 & 0.005 \\
\hline Aromatics 1 & ARO1 & $\mathrm{k}_{\mathrm{OH}}<2.0 \times 10^{4}$ & 0.064 & 0.033 & 0.011 & 0.020 & 0.014 \\
\hline Aromatics 2 & $\mathrm{ARO} 2$ & $\mathrm{k}_{\mathrm{OH}}>2.0 \times 10^{4}$ & 0.013 & 0.016 & 0.084 & 0.072 & 0.022 \\
\hline Benzaldehyde & BALD & $\mathrm{k}_{\mathrm{OH}}=1.9 \times 10^{4}$ & 0.019 & 0.000 & 0.000 & 0.003 & 0.004 \\
\hline Acetone & MEK & $\mathrm{k}_{\mathrm{OH}}<7.0 \times 10^{3}$ & 0.000 & 0.005 & 0.000 & 0.000 & 0.001 \\
\hline Acetone & PROD2 & $\mathrm{k}_{\mathrm{OH}}>7.0 \times 10^{3}$ & 0.000 & 0.010 & 0.000 & 0.000 & 0.004 \\
\hline
\end{tabular}




\begin{tabular}{|c|c|c|c|c|c|c|c|}
\hline \multirow{3}{*}{$\begin{array}{l}\text { Compound or } \\
\text { Group }\end{array}$} & \multirow{3}{*}{ Symbol } & \multirow{3}{*}{$\begin{array}{c}\text { Reactivity } \\
\mathrm{k}_{\mathrm{OH}}\left(\mathrm{ppm}^{-1} \mathrm{~min}^{-1}\right)\end{array}$} & \multicolumn{5}{|c|}{ Fraction (on a ppmC basis) } \\
\hline & & & \multicolumn{3}{|c|}{$\begin{array}{l}\text { Santos-Dumont } \\
\text { Airport }\end{array}$} & \multirow{2}{*}{$\begin{array}{c}\text { International } \\
\text { Airport } \\
\text { Site } 4\end{array}$} & \multirow{2}{*}{$\begin{array}{c}\text { Downtown } \\
\text { Site } 5\end{array}$} \\
\hline & & & $\begin{array}{c}\text { Site } \\
1 \\
\end{array}$ & $\begin{array}{l}\text { Site } \\
2 \\
\end{array}$ & $\begin{array}{c}\text { Site } \\
3 \\
\end{array}$ & & \\
\hline Methane & $\mathrm{CH}_{4}$ & $\mathrm{k}_{\mathrm{OH}}=9.7 \times 10$ & 0.592 & 0.721 & 0.685 & 0.675 & 0.795 \\
\hline Ethanol & ETOH & $\mathrm{k}_{\mathrm{OH}}=4.9 \times 10^{3}$ & 0.006 & 0.007 & 0.019 & 0.019 & 0.007 \\
\hline Formaldehyde & $\mathrm{HCHO}$ & $\mathrm{k}_{\mathrm{OH}}=1.4 \times 10^{4}$ & 0.011 & 0.014 & 0.036 & 0.035 & 0.018 \\
\hline Acetaldehyde & $\mathrm{CCHO}$ & $\mathrm{k}_{\mathrm{OH}}=2.3 \times 10^{4}$ & 0.006 & 0.008 & 0.019 & 0.019 & 0.010 \\
\hline
\end{tabular}

Site 5 - Presidente Vargas Avenue

Table 4 - Ranking, according to mass concentration, reaction rate with $\mathrm{OH}$ and production of ozone, of $\mathrm{VOC}$ collected in Site 1, $10 \mathrm{~m}$ from the runway in Santos-Dumont Airport, Rio de Janeiro.

\begin{tabular}{|c|c|c|c|c|c|}
\hline \multicolumn{2}{|l|}{ Mass concentration $^{a}$} & \multicolumn{2}{|l|}{ Reaction with $\mathrm{OH}^{\text {b }}$} & \multicolumn{2}{|l|}{ Ozone formation $^{\mathrm{c}}$} \\
\hline Toluene & 211 & Cis 2-Butene & 103 & Toluene & 838 \\
\hline Isopentane & 190 & 2-Methyl-1-butene & 90 & Cis 2-Butene & 546 \\
\hline$n$-Butane & 125 & Toluene & 67 & 2-Methyl-1-propene & 498 \\
\hline$n$-Pentane & 108 & 2-Methyl-1-propene & 48 & 1-Butene & 367 \\
\hline Benzaldehyde & 128 & 1-Butene & 48 & Isopentane & 319 \\
\hline 3-Methyl-1-butene & 63 & Benzaldehyde & 41 & 2-Methyl-1-butene & 272 \\
\hline 2-Methyl-1-propene & 43 & 2-Pentene & 30 & 2-Pentene & 175 \\
\hline 2-Methyl-1-butene & 42 & Isopentane & 29 & $n$-Butane & 167 \\
\hline 2-Methylpentane & 42 & Ciclopentene & 20 & $n$-Pentane & 166 \\
\hline Isobutane & 35 & 1,3,5-Trimethylbenzene & 20 & 1,3,5-Trimethylbenzene & 86 \\
\hline Cis 2-Butene & 40 & 3-Methyl-2-pentene & 19 & 2-Methylpentane & 75 \\
\hline 1-Butene & 35 & $n$-Pentane & 18 & $m$-Xylene & 75 \\
\hline 1,2-Dichlorobenzene & 25 & $n$-Butane & 13 & 3-Methyl-2-pentene & 60 \\
\hline 2-Pentene & 23 & 2-Methyl-2-pentene & 10 & Isobutane & 47 \\
\hline n-Hexane & 22 & 2-Methylpentane & 9 & Cis 2-Hexene & 44 \\
\hline 1.2-Dimethylcyclopropane & 17 & $m$-Xylene & 8 & $m$-Ethyltoluene & 43 \\
\hline 2-Methyl-2-butene & 16 & 2-Methyl-1-pentene & 7 & 1,3-Dimethylcyclopentane & 42 \\
\hline 3-Methylpentane & 15 & 1,3-Dimethylcyclopentane & 6 & $o$-Xylene & 41 \\
\hline 1,3-Dichlorobenzene & 11 & 1,2,4-Trimethylbenzene & 6 & o-Ethyltoluene & 36 \\
\hline 1,3,5-Trimethylbenzene & 8 & $n$-Hexane & 5 & $p$-Xylene & 34 \\
\hline$p$-Xylene & 7 & $p$-Xylene & 5 & $n$-Hexane & 32 \\
\hline$m$-Xylene & 7 & $m$-Ethyltoluene & 4 & 3-Methylpentane & 31 \\
\hline o-Xylene & 6 & $o$-Xylene & 3 & 1,2,4-Trimethylbenzene & 27 \\
\hline
\end{tabular}

${ }^{a}$ Units: micrograms per cubic meter.

${ }^{\mathrm{b}}$ Product of VOC concentration (units: ppmC) and COV-OH reaction rate constant (units: $\mathrm{ppmC}^{-1} \mathrm{~s}^{-1}$ ).

${ }^{\mathrm{c}}$ Product of VOC concentration (units: $\mu \mathrm{gm}^{-3}$ ) and MIR coefficient (dimensionless, gram of ozone produced per gram of VOC). 